\title{
STRATEGI PENINGKATAN PENGELOLAAN BARANG MILIK DAERAH PADA PEMERINTAH KABUPATEN KEPULAUAN ANAMBAS
}

\author{
Improvement Strategy for Assets Management at Anambas Regional Government
}

\author{
Khoirul Syahputra1, Yusman Syaukat ${ }^{2}$, Abdul Kohar Irwanto ${ }^{3}$ \\ 1Staf Dikpora, Kabupaten Kepulauan Anambas, Provinsi Kepulauan Riau. E-mail : dikporairulsy@gmail.com \\ 2Staff Pengajar Departemen Ekonomi Sumberdaya dan Lingkungan. Fakultas Ekonomi dan Manajemen. IPB. E- \\ mail : ysyaukat@gmail.com \\ ${ }^{3}$ Staff Pengajar Departemen Manajemen. Fakultas Ekonomi dan Manajemen. IPB. E-mail : \\ irwanto.abdulkohar@yahoo.com
}

\begin{abstract}
Reformation agenda is in various fields. One of the reformation agenda is in implementing the good governance. Regulation of the home affairs minister No. 19 Year 2016 is the regulation to rule local government wealth becoming adequated, informative, transparent and accountable. The purpose of this study are evaluating, knowing and describing the regional management assets. This study also formulating priority strategies to improve regional assets management of the Anambas government. The data consists of primary and secondary data. Primary data was obtained from direct observation, interview and questioners with purposive sampling method. While the secondary data was obtained from literature and related documents. This study use rating scale analysis, SWOT and QSPM analysis. This study has shown the weaknesses of the human resources competeny in assets management was caused by lackig in guidance, supervision and controlling which influenced the assets managements performance. The priority strategy was improving the quality of human resources in managing and reporting the local goverment assets.
\end{abstract}

Key words: Strategy, improvement management of BMD

\begin{abstract}
ABSTRAK
Reformasi diberbagai bidang di pemerintahan salah satunya adalah manisfestasi pelaksanaan prinsip tata kelola pemerintahan yang baik (good governance), Permendagri No. 19 Tahun 2016 tentang pengelolaan BMD adalah wujudnya aturan yang mengatur suatu sistem pengelolaan kekayaan daerah yang memadai, informatif, transparan dan akuntabel. Tujuan penelitian ini untuk mengevaluasi, mengetahui dan mendeskripsikan proses pengelolaan BMD dan merumuskan strategi yang perlu diprioritaskan dalam meningkatkan pengelolaan BMD pada Pemerintah Kabupaten Kepulauan Anambas. Data penelitian ini terdiri dari data primer dan data sekunder, data primer diperoleh dengan cara observasi langsung, wawancara dan penyebaran kuesioner kepada responden yang dipilih secara sengaja (purposive sampling). Sedangkan untuk mendapatkan data sekunder berasal dari studi pustaka dan kajian terhadap dokumen terkait. Metode analisis yang digunakan untuk menjawab tujuan penelitian adalah : analisis rating scale, analisis SWOT dan metode QSPM. Hasil penelitian menunjukkan bahwa lemahnya komptensi SDM pengelola BMD tidak terlepas dari kurang optimalnya pembinaan, pengawasan dan pengedalian pada pengurus BMD dan ini juga berdampak pada kinerja aparatur pengelola BMD. Strategi prioritas yang tepat untuk diimplementasikan yaitu peningkatan kualitas SDM pengurus BMD dalam mengelola dan menyusun laporan BMD.
\end{abstract}

Kata kunci: Strategi, Peningkatan Pengelolaan BMD.

\section{PENDAHULUAN}

$\begin{array}{rrr}\text { Salah } & \text { satu } & \text { manisfestasi } \\ \text { pelaksanaan } & \text { prinsip } & \text { tata }\end{array}$

pemerintahan yang baik (good governance) yang menjadi tuntutan masyarakat adalah terwujudnya suatu sistem pengelolaan kekayaan daerah yang 
memadai, informatif, transparan, dan akuntabel (Suwanda, 2015). Koridor pengelolaan barang milik daerah memberikan acuan bahwa barang milik daerah harus digunakan semaksimal mungkin mendukung kelancaran tupoksi pelayanan, dan memberikan manfaat kontribusi penerimaan bagi daerah.

Pengelolaan barang milik daerah masih menjadi permasalahan klasik di berbagai daerah. Ketidakpedulian terhadap pengelolaan dan pemeliharaan barang milik daerah yang tidak teratur, tertib dalam melaksanakan ketentuan pengelolaan barang milik daerah dapat terlihat dari catatan atas opini Badan Pemeriksa Keuangan (BPK) terhadap keuangan pemerintah daerah yang hampir setiap tahun masih didominasi masalah penyajian aset tetap.

Permasalahan yang sering terjadi di pemerintah daerah adalah belum diterapkannya secara benar aturan pengelolaan barang milik daerah yang berakibat pada proses perencanaan pengangaran pengadaan barang yang tidak sesuai dengan peruntukannya, penggunaan barang milik daerah yang tidak sesuai penetapan penggunaan, kemudian pemerintah daerah tidak melakukan kapitalisasi terhadap biayabiaya yang menambah harga perolehan aset tetap. Barang-barang yang dibiarkan dan tidak terpelihara diambil alih oleh pihak lain, bahkan aset tetap/BMD tidak dapat ditelusuri keberadaannya serta kehilagan aset tetap tidak terdeteksi. Barang yang tidak dikembalikan ke SKPD oleh pejabat yang telah pensiun, dan ada juga aset warisan daerah Kabupaten induk yang diserahkan kepada daerah yang dimekarkan tidak didukung dengan rincian data yang informatif dan tidak disertai bukti kepemilikan (Halim, 2013).

Praktik pengelolaan dan penanganannya yang belum optimal, pemerintah telah mengeluarkan Peraturan Pemerintah Nomor 27 tahun 2014 dan Permendagri Nomor 19 Tahun 2016 tentang pengelolaan barang milik daerah yang terdiri dari 11 tahapan untuk mengatur dan menjawab berbagai permasalahan tersebut. Menurut Soleh dan Rochmansjah (2010), dari tahapantahapan pengelolaan barang milik negara/daerah tersebut dapat disederhanakan menjadi: (1) adanya perencanaan yang tepat, (2) pelaksanaan secara efisien dan efektif dan (3) pembinaan, pengawasan dan pengendalian.

Berdasarkan hasil pemeriksaan BPK dalam rentang waktu tahun 2009 sampai tahun 2015, LKPD Kabupaten Kepulauan Anambas pernah berada pada posisi opini terendah Tidak Memberikan Pendapat (TMP/disclaimer) pada tahun 2009, dan LKPD di 5 tahun berturut-turut (2010-2014) hanya meraih Wajar Dengan Pengecualian (WDP). Terakhir, pada tahun 2015, laporan keuangan Pemerintah Kabupaten Kepulauan Anambas meraih opini Wajar Tanpa Pengecualian (WTP) dari BPK RI, namun masih terdapat catatan permasalahan yang harus diselesaikan terkait dengan pengelolaan barang milik daerah (aset).

Opini disclaimer untuk LHP tahun 2009 yang diberikan BPK RI atas LHP Pemkab Anambas disebabkan karena ketidaksesuaian penyajian dengan Standar Akuntansi Pemerintah (SAP), terutama terhadap akun-akun belanja barang perbedaan nilai neraca dengan pembukuan inventaris barang dan kondisi barang yang tidak ditemukan. Kelemahan dalam pengelolaan barang milik daerah karna pengendalian intern tidak berjalan dengan baik. Ketidakpatuhan terhadap ketentuan perundang-undangan serta ketidakcukupan pengungkapan laporan barang.

Berkaitan pengelolaan BMD dengan pencatatan dan opini BPK terhadap LKPD pemerintah daerah adalah; pengelolaan BMD ini merupakan tahapan untuk proses mengatur BMD agar terkola dengan baik dan tersajikan pelaporannya secara administrasi yang akurat, teratur dan akuntabel. Laporan 
barang barang milik daerah (LPBMD) ini merupakan bagian dari laporan keuangan yang menjelaskan pengungkapan dan penyajian data mengenai kondisi keseluruhan aset, hal ini didapat dari penatausahaan pembukuan pencatatan aset di buku inventaris barang LPBMD yang mempuyai neraca barang yang akan singkronkan dengan laporan neraca keuangan SKPD. Laporan keuangan SKPD merupakan unit-unit akutansi pelaporan yang akan di konsolidasi dan digambungkan menjadi satu laporan keuangan pemerintah daerah (LKPD). LKPD ini akan diaudit dan diberikan penilaian oleh BPK terhadap pertanggungjawaban pengelolaan dan pengunaan dana yang dikeluarkan pemerintah daerah apakah sudah sesuai dengan SAP, SPI, Disclosure dan ketaatan terhadap perundang-udangan. Hal ini merupakan hal yang sangat menarik untuk dikaji lebih lanjut.

Motivasi-motivasi tersebut menjadi topik yang menarik untuk diteliti, sehingga perlu diketahui faktor kelemahan dan kekuatan dalam pengelolaan BMD pada Pemerintah Kabupaten Kepulauan Anambas dalam upaya tertib administrasi dan berkelanjutan dalam mempertahankan opini WTP yang telah diraih.

Tujuan dari penelitian ini adalah : (1) Mengevaluasi proses perencanaan kebutuhan pengangaran, pelaksanaan dan pembinaan, pengawasan pengendalian dalam pengelolaan barang milik daerah pada Pemerintah Kabupaten Kepulauan Anambas. (2) Mengidentifikasi faktorfaktor apa yang menjadi kekuatan dan kelemahan dalam pengelolaan barang milik daerah dan merumuskan strategi alternatife. (3) Merumuskan strategi yang diprioritaskan dan perancangan program dalam peningkatan pengelolaan barang milik daerah pada Pemerintah Kabupaten Kepulauan Anambas.

\section{METODOLOGI}

Penelitian dilakukan di Kabupaten Kepulauan Anambas Provinsi Kepulauan Riau tepatnya pada Badan Keuangan Daerah (BKD). Badan Keuangan Daerah merupakan SKPD yang melaksanakan pengelolaan keuangan daerah dan aset di Kabupaten Kepulauan Anambas. Jenis data yang digunakan dalam penelitian ini terdiri dari data primer dan data sekunder. Data primer diperoleh dengan cara observasi langsung, wawancara dan penyebaran kuesioner. Sedangkan untuk mendapatkan data sekunder berasal dari studi pustaka dan kajian terhadap literatur terkait.

Responden terdiri dari penguna barang/pejabat yang ditunjuk pengurus barang di SKPD dan pimpinan Badan Keuangan Daerah yang berhubungan langsung dan bertanggung jawab terhadap pengelolaan keuangan dan aset di Kabupaten Kepulauan Anambas dan dipilih secara purposive sampling. Pemilihan responden berdasarkan pertimbangan bahwa responden merupakan pejabat yang bertugas melakukan penyusunan laporan BMD yang sesuai tugas pokok dan fungsinya seperti yang tercantum dalam Peraturan Menteri Dalam Negeri Nomor 19 Tahun 2016 tentang teknis Pengelolaan Barang Milik Daerah pasal 1 ayat 19. Data sekunder diperoleh dari Laporan Hasil Pemeriksaan Badan Pemeriksa Keuangan tahun 2011 - 2015, dokumen serta regulasi terkait dan relevan dalam penelitian ini. Alat analisis yang digunakan untuk sesuai dengan urutan tujuan dalam penelitian ini adalah: (1) Analisis ratting scale, (2) analisis SWOT serta (3) analisis Quantitative Strategic Planning Matrix (QSPM).

Analisis rating scale dilakukan untuk mengukur dan melakukan evaluasi sehingga dapat membandingkan kondisi sesungguhnya mengenai pengelolaan BMD yang dilihat dari LPBMD pada saat ini. Menurut Riduwan (2010) dalam rating scale responden akan menjawab 
salah satu data kuantitatif yang telah disediakan. Analisis rating scale dilakukan melalui pengisian kuesioner oleh Pengurus barang. Penentuan skor menggunakan skala penilaian $1-4$ terhadap seluruh tahapan dalam pengelolaan BMD.

Untuk mengidentifikasi faktor kelemahan dan kekuatan yang berpengaruh terhadap pengelolaan dan pelaporan BMD peneliti melakukan wawancara terhadap responden yang compatibel dalam menentukan arah kebijakan pengelolaan BMD di kabupaten tersebut ( Ka. BKD, Kabit Aset BKD, Kepala Seksi Aset, pengurus BMD SKPD yang memiliki jumlah aset yang besar) dan kajian pustaka.

Analisis SWOT perlu dilakukan untuk menetapkan pemilihan strategi yang paling tepat dalam rangka peningkatan pengelolaan BMD pada Pemerintah Kabupaten Kepulauan Anambas. Adapun faktor penting yang menjadi tujuan dalam pemilihan strategi peningkatan pengelolaan BMD maka dimasukan kedalam faktor kunci internal (IFE) dan faktor kunci eksternal (EFE). Penentuan bobot dilakukan dengan mengajukan identifikasi faktor internal dan eksternal kepada stakeholder dengan menggunakan metode paired comparison (Kinnear, 1991). Metode ini digunakan untuk memberikan penilaian terhadap bobot di setiap faktor-faktor internal dan eksternal.

Penggunaan analisis QSPM bertujuan untuk memperoleh prioritas strategi terbaik yang paling menarik untuk diimplementasikan sesuai dengan arah dan kebijakan Pemerintah Kabupaten Kepulauan Anambas dalam hal pengelolaan BMD. Analisis QSPM menggunakan skor daya tarik atau Atrractiveness Scores (AS) dengan Nilai Daya Tarik adalah $1=$ tidak menarik, $2=$ agak menarik, $3=$ cukup menarik, $4=$ sangat menarik. Penentuan prioritas strategi terbaik dilakukan dengan cara menentukan rating atau tingkat ketertarikan relatif dari strategi-strategi yang telah dipilih. Nilai Total Attractiveness Scores (TAS) tertinggi menandakan strategi yang paling layak untuk diimplementasikan dengan memperhatikan seluruh faktor internal dan eksternal.

\section{HASIL DAN PEMBAHASAN}

\section{Evaluasi pengelolaan BMD pada Pemerintah Kabupaten Kepulauan Anambas}

Dalam bab ini akan dijelaskan hasil evaluasi implementasi terhadap pengelola BMD untuk menjawab tujuan penelitian tentang kondisi pengelolaan BMD. Kuesioner yang disebarkan bertujuan untuk mengukur dan mengevaluasi terhadap seluruh proses pengelolaan BMD mulai dari proses perencanaan, pelaksanaan dan pembinaan, pengawasan dan pengedalian. Berdasarkan hasil pengolahan data terhadap kuesioer diperoleh jawaban masing-masing tahapan pengelolaan BMD sebagaimana disajikan pada Tabel 1.

Tabel 1. Penilaian Responden Terhadap Kondisi Pengelolaan BMD

\begin{tabular}{lcccccc}
\hline \multicolumn{1}{c}{ Variabel } & Pernyataan & Skor & $\begin{array}{c}\text { Skor } \\
\text { Maksimum }\end{array}$ & Rata-rata & TCR (\%) & Kriteria \\
\hline $\begin{array}{l}\text { Perecanaan kebutuhan dan } \\
\text { penganggaran }\end{array}$ & Prc 8 & 694 & 832 & 3,34 & 83,41 & Baik \\
$\begin{array}{l}\text { Pelaksanaan } \\
\begin{array}{l}\text { Pembinaan, Pengawasan dan } \\
\text { pengendalian }\end{array}\end{array}$ & Pls 21 & 1835 & 2184 & 3,45 & 84,02 & Baik \\
& Pbot Pgw 7 & 525 & 728 & 2,88 & 72,12 & Kurang \\
& & 3054 & 3744 & 3,23 & 79,85 & Baik \\
\hline
\end{tabular}


Dari Tabel 1 secara keseluruhan pegukuran nilai skor dari masing-masing tahapan yang dilakukan terhadap proses pengelolaan BMD diperoleh hasil bahwa nilai pengelolaan BMD secara keseluruhan berada pada nilai 3,23 dalam kategori baik. Secara tahapan pengelolaan BMD, tahapan perencanaan dan pelaksanaan berada pada kategori baik dengan nilai 3,34 dan 3,45, sedangkan tahapan pembinaan, pengawasan dan pengendalian dalam kategori kurang baik dengan nilai 2,88. Nilai keseluruhan tahapan pada siklus pengelolaan BMD adalah 3054 dengan persentase sebesar $79.85 \%$ dari skala kriterium atau 3.23 (likert skala 4).

\section{Perencanaan Kebutuhan dan Penganggaran}

Perencanaan Kebutuhan adalah kegiatan merumuskan rincian kebutuhan BMD untuk menghubungkan pengadaan barang yang telah lalu dengan keadaan yang sedang berjalan sebagai dasar dalam melakukan tindakan yang akan datang. Berdasarkan hasil analisis yang dilakukan terhadap tahapan proses perencanaan kebutuhan dan penganggaran BMD melalui pengisian kuisioner oleh responden, diperoleh hasil jumlah skor total rata-rata adalah 694 dengan persentase sebesar $83.41 \%$ dari skala kriterium atau 3.34 (likert skala 4). Hasil perolehan skor menunjukkan bahwa perencanaan dan penganggaran sudah baik namun belum optimal dan masih harus dilakukan berbagai perbaikan pada indikator yang dinilai masih kurang.

Penilaian terhadap perencanaan kebutuhan dan penganggaran masih terdapat proses perencanaan yang kurang baik yaitu; pada Prc 1 dengan nilai 2,88, Prc 2 dengan skor 2,85 dan Prc 6 dengan skor 2,92. Hasil ini menunjukan bahwa sebagian besar SKPD tidak membuat analisa rancangan kebutuhan barang dan pemeliharaan barang. Hal ini disebabkan karena ketidakpahaman pengguna/

84 pengurus barang yang di SKPD terkait dengan fungsi dan tujuan analisa/telaah perencanaan dalam meyusun kebutuhan barang. Tidak dilaksanakannya proses tersebut akan mengakibatkan pemborosan keuangan daerah. Salah satu SKPD yang ditemui oleh peneliti mengenai barang mesin foto copy yang tidak dapat dimanfaatkan menyatakan bahwa pengadaan ini diperuntukan untuk UPT pendidikan di tujuh kecamatan dan diserahkan ke UPT dengan kondisi siap dioperasikan, namun setelah barang sampai di UPT Pedidikan tidak bisa dioperasikan. Barang tidak bisa digunakan karena di UPT pendidikan tidak didukung dengan kondisi kapasitas listrik yang memadai. Hal ini disebakan tidak adanya analisa sebelum perencanaan dalam pengadaan barang dan tidak didasarkan kebutuhan yang diinginkan yang menjadi prioritas.

\section{Pelaksanaan}

Berdasarkan hasil pengolahan data yang dilakukan menunjukkan bahwa skor total yang diperoleh dari hasil pengisian kuesioner terhadap pelaksanaan pengelolaan BMD sebesar 1835 dengan persentase sebesar 84,02 \% dari skala kriterium atau 3,45 (likert skala 4). Hasil perolehan skor total berada pada interval baik, namun perlu dipertahankan dan meningkatkan sistim adminisrasi pengelolaannya menjadi lebih baik lagi untuk tahun berikutnya. Hal ini menggambarkan bahwa masih perlu dilakukan berbagai perbaikan dalam implementasi pelaksanaan dari segi pengamanan dan pemeliharaan, serta penatausahaan.

Berdasarkan hasil evaluasi kuesioner dari responden disimpulkan bahwa Pemerintah Kabupaten Kepulauan Anambas belum melakukan pengamanan BMD secara baik. Hal ini dilihat dari hasil evaluasi Pgm 1, SKPD melakukan pengamanan BMD baik secara administrasi, fisik, maupun hukum dengan skor 2,96 dalam kategori kurang. Secara administrasi pengamanan sudah dilakukan dengan menghimpun, mencatat, menyimpan dan menatausahakan secara tertib, namun pengamanan adminstrasi BMD belum diikuti dengan pengisian 
atribut BMD dalam aplikasi SIMDA BMD. Selain itu secara fisik, barangbarang milik Kabupaten Anambas seperti tanah dan bangunan belum dipasang tanda (plang penanda) sebagai identitas aset milik daerah. Dari sisi pengaman barang secara hukum masih banyak tanah milik Kabupaten Anambas yang belum disertifikasi. Untuk barang bergerak seperti kendaraan, BPKB kendaraan tersebut tidak jelas keberadaannya.

Terkait dengan lemahnya pengamanan fisik dan hukum aset tetap tanah yang tidak didukung dengan dokumen seperti surat tanah, hal ini merupakan fakta yang ditemukan dalam penelitian. Bangunan/gedung UPT Pendidikan Kecamatan Siantan Tengah yang sudah dibangun namun status lahan yang digunakan masih bersifat hibah dan baru sebatas pembicaraan belum didukung dengan dokumen yang berkekuatan hukum berbentuk akta atau surat tanah (surat hibah tanah).

Bentuk lain dari pengamanan administrasi yang harus dilakukan oleh Pemerintah Daerah adalah pemasangan label identitas asset. Hasil kuesioner tentang pemasangan label (Pgm 2) diperoleh skor 2,88 dalam kategori kurang. Berdasarkan hasil lapangan, masih banyak asset-aset milik Kabupaten Anambas yang belum dipasang label sebagai identitas milik daerah. Pemasangan label ini belum dilakukan karena belum tersedianya anggaran yang cukup untuk pemasangan label. Selain itu kurangnya koordinasi antara pembantu pengelola (BKD) dengan SKPD pengguna terkait dengan bentuk dan tata cara pengisian serta pemasangan label juga menjadi penyebab belum dilakukannya pemasangan label.

Terkait dengan pemeliharaan barang, SKPD pengguna barang wajib membuat laporan hasil pemeliharaan barang. Hasil dari kuesioner memperoleh skor 2,92 dalam kategori kurang. Hasil penelitian lapangan tentang laporan pemeliharaan barang, tidak ditemukan adanya SKPD yang membuat dan melaporkan hasil pemeliharaan barang.
Didalam LHP BPK 03.C/LHP/XVIII.TJP/ 05/2016 tanggal 23 Mei 2016 Aset tetap hibah penyerahan dari Kabupaten Natuna, berupa bangunan dari KKKS Conocophilips belum dilengkapi dokumen surat kepemilikan gedung, surat tanah serta harga perolehannya.

Berdasarkan hasil analisa rating scale dijelaskan secara keseluruhan tetang kondisi di beberapa SKPD sudah baik, namun masih ada yang harus dilakukan perbaikan dalam pelaksanaannya yaitu pada Pnt 2 dengan skor 2.96 bahwa pegurus barang sebagai operator SIMDABMD belum melakukan verifikasi data dan kelengkapan asset untuk pencatatan dan pengimputan data asset/barang kedalam aplikasi untuk dilaporkan. Selain itu masih terdapat hasil kuisioner masih kurang yaitu Pnt 4 dengan skor 2,92 bahwa pengurus tidak melakukan perubahan jumlah BMD berkurang mutasi barang dan penyusutan. Hal ini terlihat dari hasil temuan BPK No. 03.A/LHP/XVIII.TJP/5/2016 bahwa pencatatan belum dilakukan terhadap belanja barang dan inventaris sekolah dari dana BOS yang yang seharusnya sudah tercatat dalam neraca keuangan Pemerinah Kabupaten Kepulauan Anambas, serta pencatatan pada gedung pertokoan/koperasi permanen merupakan revitalisasi bangunan pasar lama menjadi gedung pertokoan/koperasi permanen baru. Nilai bangunan lama tercatat senilai Rp1,00 pada KIB C Sekretariat Daerah dan merupakan hibah aset tetap dari Pemerintah Kabupaten Natuna. Namun pencatatan pada Kartu Inventaris Barang (KIB) $\mathrm{C}$ pada Dinas Perindustrian, Perdagangan, Koperasi dan UKM (Disperindagkop dan UKM) diketahui adanya BMD berupa gedung pertokoan/ koperasi permanen sebagai lokasi perdagangan (bangunan pasar baru) senilai Rp 1.967.460.000,00. Permasalahan ini terjadi karena ketidakpahaman pengelola BMD dan pengguna barang di SKPD tentang kejelasan tanggung jawab pengunaan barang serta kurang melakukan koordinasi. 


\section{Pembinaan, Pengawasan dan Pengendalian terhadap Pengelolaan Barang Milik Daerah}

Kegiatan pembinaan, pengawasan dan pengendalian merupakan unsur ketiga dari tahapan pengelolaan BMD. Dalam unsur ini yang dilihat bagaimana aktivitas kemampuan SKPD pada pemerintah Kabupaten Kepulauan Anambas dalam melakukan pembinaan, pengawasan dan pengendalian dalam pengelolaan BMD. Berdasarkan pengukuran yang dilakukan terhadap variabel ini, skor total yang diperoleh adalah 525 dengan persentase $72.12 \%$ dari skala kriteriun atau 2,88 (Likert Skala 4). Hasil ini menunjukan bahwa implementasi evaluasi pembinaan, pegawasan dan pengendalian BMD pada Pemerintah Kabupaten Kepualauan Anambas sudah berjalan tetapi masih kurang baik.

Hasil evaluasi penilaian variable pembinaan, pengawasan dan pengendalian terhadap pengelolaan BMD dinilai kurang baik. Pada Pbn 1 skor 2,81 adalah responden menilai bahwa pengurus barang masih kurang diberikan pendidikan dan pelatihan tentang pengelolaan BMD. Pgw 1 dengan skor 2,85 dinilai kurang baik disebabkan kurangnya sosialisasi tentang uraian tugas dan wewenang pengurus barang dalam pelaksanaan lapangan. Pembinaan dan pengawasan adalah salah satu bentuk pengendalian internal SKPD yang belum terlaksana secara maksimal karena tipikal kepemimpinan yang berbeda. Pada beberapa SKPD pengawasan sudah berjalan secara baik pada sebagian SKPD lagi masih dianggap kurang. Berdasarkan pendapat responden diperoleh data masih terdapat pemimpin SKPD secara manajerial masih belum mengawasi dan mengecek kondisi BMD dalam kewenangannya untuk mengantisipasi penyimpangan yang mungkin akan terjadi. Kurangnya keberpihakan (awareness) pimpinan SKPD merupakan hal yang perlu

mendapat perhatian karena pengelolaan keuangan masih dianggap sebagai suatu hal yang paling utama sehingga pengelolaan BMD belum menjadi prioritas.

Pimpinan SKPD belum melakukan pembinaan pada pegawainya, untuk meningkatkan kompetensi dan kinerja penatausahaan barang daerah pada SKPD. Wujud dari pembinaan pegawai adalah dengan melihat hasil kerja yang telah mereka lakukan apakah sudah sesuai dan berjalan berdasarkan aturan pengeloloaan BMD. Kondisi existing adalah pimpinan SKPD lebih banyak bersikap pasif sehingga hanya menunggu program peningkatan kompetensi yang dilakukan oleh BKPSDM dan BKD. Disamping hal tersebut belum adanya aturan dari pimpinan SKPD untuk mewajibkan pegawai yang selesai mengikuti kegiatan peningkatan kompetensi dalam penatausahaan BMD untuk mensosialisasikan kepada pegawai lainnya dikantor sendiri dalam wujud Pelatihan di Kantor Sendiri (PKS) sehingga pegawai yang bukan mengurusi BMD juga aware terhadap BMD.

\section{Strategi Peningkatan Pengelolaan Barang Milik Daerah Pemerintah Identifikasi Faktor Kunci Eksternal dan Internal}

Berdasarkan hasil wawancara yang dilakukan dengan pimpinan Badan Keuangan Daerah dan kajian terhadap dokumen terkait, diperoleh 22 (dua puluh dua) faktor strategis yang berperan dalam peningkatan pengelolaan BMD Pemerintah Kabupaten Kepulauan Anambas. Langkah selanjutnya adalah memberikan kuesioner kepada informan Badan Keuangan Daerah untuk melakukan penilaian atas faktor internal dan eksternal. Hasil penilaian atas faktor internal dan eksternal menggunakan Internal Factor Evaluation (IFE) dan External Factor Evaluation (EFE) disajikan dalam Tabel 3 dan Tabel 4.

Hasil perhitungan IFE
menunjukkan total nilai tertimbang untuk faktor kekuatan sebesar 2,012 dan 0,759 untuk faktor kelemahan. Hal ini mengindikasikan bahwa Pemerintah Kabupaten Kepulauan Anambas berada 
dalam posisi internal yang kuat dan memiliki kekuatan yang lebih besar dibandingkan faktor kelemahannya. Hasil perhitungan IFE menunjukkan bahwa kebijakan pemerintah daerah dalam mendukung pengelolaan keuangan sebagai kekuatan utama bagi Pemerintah Kabupaten Kepulauan Anambas dengan nilai tertimbang paling tinggi sebesar 0,460 yang ditunjukkan dengan nilai rating 4 . Faktor ini merupakan salah satu faktor kekuatan yang terpenting karena memiliki bobot paling tinggi sebesar 0,115 .
Berdasarkan perhitungan lemahnya kompetensi aparatur pengelola BMD menjadi kelemahan bagi Pemerintah Kabupaten Kepulauan Anambas dengan nilai tertimbang sebesar 0,165 . Lemahnya kompetensi pengelola BMD Pemerintah Kabupaten Kepulauan Anambas sesuai dengan hasil yang diperoleh berdasarkan wawancara dengan pengurus barang dan Kabid Aset BKD menyatakan bahwa masih kurangnya pelatihan yang diselenggarakan bagi pengelola BMD.

Tabel 3. Analisis IFE Peningkatan Pengelolaan BMD Pemerintah Kabupaten Kepulauan Anambas

\begin{tabular}{|c|c|c|c|c|}
\hline No. & Kekuatan & Bobot & Rating & Skor \\
\hline 1 & $\begin{array}{l}\text { Kebijakan Pemerintah Daerah dalam mendukung } \\
\text { pengelolaan BMD }\end{array}$ & 0.115 & 4.00 & 0.460 \\
\hline 2 & $\begin{array}{l}\text { Manajemen dan Struktur Organisasi tupoksi yang } \\
\text { jelas bagi pengelola BMD }\end{array}$ & 0.100 & 3.33 & 0.332 \\
\hline 3 & $\begin{array}{l}\text { Komitmen pimpinan BKD yang kuat dalam } \\
\text { pengelolaan BMD tentang rekosiliasi data aset dan } \\
\text { keuangan. }\end{array}$ & 0.110 & 4.00 & 0.442 \\
\hline 4 & $\begin{array}{l}\text { Adanya Standar Operasional Prosedur (SOP) dalam } \\
\text { penyusunan laporan BMD }\end{array}$ & 0.096 & 3.00 & 0.288 \\
\hline 5 & $\begin{array}{l}\text { Ketersediaan sarana pendukung penyusunan laporan } \\
\text { BMD yang memadai }\end{array}$ & 0.090 & 3.00 & 0.271 \\
\hline \multirow[t]{3}{*}{6} & $\begin{array}{l}\text { Aparatur pengelola BMD secara kuantitas cukup } \\
\text { memadai }\end{array}$ & 0.073 & 3.00 & 0.220 \\
\hline & Total Kekuatan & 0.585 & & 2.012 \\
\hline & Kelemahan & Bobot & Rating & Skor \\
\hline 1 & Rendahnya kualitas SDM pengelola BMD di SKPD & 0.083 & 2.00 & 0.165 \\
\hline 2 & $\begin{array}{l}\text { Pemantauan dan pengawasan } \\
\text { berkelanjutan belum memadai. }\end{array}$ & 0.071 & 1.83 & 0.130 \\
\hline 3 & $\begin{array}{l}\text { Keterbatasan pagu anggaran dalam peningkatan } \\
\text { kinerja pengelola dan pengurus BMD }\end{array}$ & 0.071 & 1.67 & 0.118 \\
\hline 4 & $\begin{array}{l}\text { Pelatihan dan sosialisasi pengelolaan BMD kurang } \\
\text { memadai. }\end{array}$ & 0.078 & 1.67 & 0.129 \\
\hline 5 & $\begin{array}{l}\text { Kompensasi dan penghargaan atas prestasi pegawai } \\
\text { pengelola, pengurus BMD belum memadai }\end{array}$ & 0.051 & 2.00 & 0.102 \\
\hline \multirow[t]{4}{*}{6} & Belum optimalnya sumberdaya Aparatur pengelola & & & \\
\hline & $\begin{array}{l}\text { BMD di Kabupaten Kepulauan Anambas dalam } \\
\text { menerapkan Standar Operasional Prosedur (SOP) }\end{array}$ & 0.063 & 2.183 & 0.115 \\
\hline & Total Kelemahan & 0.415 & & 0.759 \\
\hline & Total IFE & & & 2.772 \\
\hline
\end{tabular}

Sumber: Data diolah (2017). 


\section{Tabel 4. Analisis EFE Peningkatan Pengelolaan BMD Pemerintah Kabupaten Kepulauan Anambas}

\begin{tabular}{|c|c|c|c|c|}
\hline No. & Peluang & Bobot & Rating & Skor \\
\hline 1 & $\begin{array}{l}\text { Pemberian insentif/honorarium bagi pengelola BMD } \\
\text { dalam meningkatkan kinerja }\end{array}$ & 0.127 & 3.00 & 0.381 \\
\hline 2 & $\begin{array}{l}\text { Kebijakan implementasi Permendagri Nomor } 64 \\
\text { tahun } 2013 \text { tentang SAP berbasis akrual dalam } \\
\text { penyusunan laporan aset dan keuangan daerah. }\end{array}$ & 0.128 & 3.00 & 0.383 \\
\hline 3 & $\begin{array}{l}\text { Peningkatan pelaksanaan pengawasan melekat oleh } \\
\text { pimpinan SKPD. }\end{array}$ & 0.122 & 3.33 & 0.407 \\
\hline 4 & $\begin{array}{ll}\text { Pemberian } & \text { sanksi kepada SKPD yang belum } \\
\text { melakukan } & \text { rekonsiliasi data belanja aset dan } \\
\text { keuangan } & \end{array}$ & 0.101 & 3.67 & 0.370 \\
\hline \multirow[t]{3}{*}{5} & $\begin{array}{l}\text { Kerjasama dengan lembaga BPKP dalam evaluasi } \\
\text { pengelolaan dan laporan BMD }\end{array}$ & 0.104 & 3.00 & 0.311 \\
\hline & Total Peluang & 0.581 & & 1.852 \\
\hline & Ancaman & Bobot & Rating & Skor \\
\hline 1 & $\begin{array}{l}\text { Rendahnya kepatuhan terhadap peraturan perundang- } \\
\text { undangan }\end{array}$ & 0.101 & 2.00 & 0.220 \\
\hline \multirow{2}{*}{$\begin{array}{l}2 \\
3\end{array}$} & Perubahan masa kepemimpinan kepala daerah. & 0.077 & 2.00 & 0.154 \\
\hline & $\begin{array}{l}\text { Mutasi dan promosi jabatan terhadap aparatur } \\
\text { pengelola BMD }\end{array}$ & 0.078 & 3.00 & 0.233 \\
\hline 4 & $\begin{array}{l}\text { Perubahan SOTK pemerintah } \\
\text { pemberlakuan PP } 18 \text { Tahun } 2016 .\end{array}$ & 0.078 & 2.67 & 0.207 \\
\hline \multirow[t]{3}{*}{5} & $\begin{array}{l}\text { Pengakuan hak pribadi / kelompok / perusahaan atas } \\
\text { BMD (tanah) }\end{array}$ & 0.076 & 3.00 & 0.228 \\
\hline & Total Ancaman & 0.419 & & 1.043 \\
\hline & Total EFE & & & 2.895 \\
\hline
\end{tabular}

Sumber: Data diolah (2017)

Total nilai tertimbang atau skor untuk faktor eksternal yang menjadi peluang adalah sebesar 1,852 sedangkan untuk ancaman memilik skor atau nilai tertimbang sebesar 1,043. Hasil perhitungan ini menunjukkan bahwa Pemerintah Kabupaten Kepulauan Anambas memiliki faktor peluang yang lebih besar daripada faktor yang menjadi ancaman. Berdasarkan hasil pengolahan kuesioner menunjukkan bahwa faktor Peningkatan pelaksanaan pengawasan melekat oleh pimpinan SKPD merupakan peluang utama dengan skor tertinggi yaitu 0,407. Faktor tersebut menjadi peluang yang memiliki tingkat kepentingan tinggi karena memiliki bobot sebesar 0,122 dan respon informan terhadap faktor tersebut tinggi dengan nilai rating 3.33 .

Faktor ancaman yaitu mutasi dan promosi jabatan terhadap aparatur pengelola BMD merupakan ancaman 88 utama dengan nilai tertimbang sebesar 0,233 Faktor ini dianggap paling penting karena memiliki bobot sebesar 0,078 dan respon setiap informan dengan rating 3 . Terjadinya perubahan terhadap organisasi perangkat daerah di Lingkungan Pemerintah Kabupaten Kepulauan Anambas maka terjadi pergeseran dan mutasi ASN dan ini menjadi kendala bagi penyusunan laporan dan pendataan aset daerah. Kemudian terhadap aturan terbaru pada perubahan SOTK pemerintah daerah harus mengimplementasi PP 18 Tahun 2016. Pemberlakuan aturan ini mengaharuskan Pemerintah Kabupaten Kepulauan Anambas menggabungkan beberapa satuan kerja menjadi satu unit kerja dan pelimpahan kewenangan personel, pendanaan, sarana dan prasarana serta dokumen dari Pemerintah Kabupaten ke Pemerintah Provinsi membutuhkan penyesuaian kembali terhadap penyajian laporan BMD.

\section{Perumusan Alternatif Strategi Melalui Analisis SWOT}

Penentuan alternatif strategi dan keterkaitan antar strategi, maka perlu 
dilakukan interaksi kombinasi strategi internal maupun eksternal. Adapun perumusan strategi disusun berdasarkan faktor internal serta faktor eksternal ke dalam matriks SWOT seperti disajikan pada Lampiran 1.

Penentuan prioritas strategi dari beberapa strategi yang dihasilkan dalam matriks SWOT selanjutnya akan dilakukan menggunakan alat analisis Quantitative Strategic Planning Matrix (QSPM).

\section{Perumusan Strategi Prioritas melalui Quantitative Strategic Planning Matrix (QSPM)}

Penggunaan QSPM bertujuan untuk memperoleh prioritas strategi terbaik yang paling menarik untuk diimplementasikan sesuai dengan arah dan kebijakan Pemerintah Kabupaten Kepulauan Anambas dalam hal pengelolaan BMD, dalam penetapan strategi yang benar-benar layak dan bisa implementasikan (grand strategy). Hasil data yang diperoleh diolah dengan menggunakan analisis QSPM (Quantitative Strategic Planning Matrix). Matrik QSPM diyakini merupakan analisis yang dapat merumuskan strategi paling prioritas berdasarkan alternatif-alternatif strategi lainya.

Penentuan prioritas strategi terbaik dilakukan dengan cara menentukan rating atau tingkat ketertarikan relatif dari strategi-strategi yang telah dipilih. Nilai skor daya tarik tertinggi menandakan strategi yang paling layak untuk diimplementasikan dengan memperhatikan seluruh faktor internal dan eksternal. Hasil perumusan strategi prioritas menggunakan QSPM yang diringkas pada Tabel 5. memprioritaskan pada strategi ketiga yaitu "Meningkatkan kualitas SDM pengelola BMD dalam penyusunan laporan BMD." Dengan skor TAS sebesar 6,363. Hasil perumusan strategi berdasarkan penilaian informan ahli ini sesuai dengan hasil analisis tujuan ketiga bahwa masih terdapat kelemahan dalam pembinaan, pengawasan dan pengendalian pengelolaan BMD. Lemahnya sistem pengawasan dan pengendalian ini diperkuat oleh temuan Badan Pemeriksa Keuangan pada LHP Pemerintah Kabupaten Kepulauan Anambas tahun 2015 nomor 03.C/LHP/ XVIII.TJP/5/2016 yang menyatakan bahwa sistem pengendalian intern Pemerintah Kabupaten Kepulauan Anambas belum memadai sehingga mengakibatkan rendahnya kepatuhan terhadap peraturan perundang-undangan. Rendahnya kepatuhan terhadap peraturan perundang-undangan diakibatkan kurangnya kompetensi SDM pengelola BMD dalam memahami peraturan terkait dalam membuat pelaporan BMD.

Hal ini mengindikasikan bahwa Pemerintah Kabupaten Kepulauan Anambas perlu melakukan percepatan dalam meningkatkan kualitas SDM pengelola BMD termasuk dalam hal kompetensinya serta keahliannya sehingga diharapkan akan terjadi peningkatan dalam pengelolaan BMD dan menjadikan kualitas pelaporan keuangan lebih baik kedepannya. 


\section{Tabel 5. Hasil analisis QSPM}

\begin{tabular}{|c|c|c|c|}
\hline No. & Strategi & TAS & Peringkat \\
\hline 1. & Peningkatan kinerja pengelola BMD & 6.199 & 2 \\
\hline 2. & $\begin{array}{l}\text { Menerapkan sanksi yang tegas dalam mendukung komitmen pimpinan BKD } \\
\text { dalam melakukan rekonsiliasi data keuangan dan aset daerah }\end{array}$ & 6.010 & 4 \\
\hline 3. & $\begin{array}{l}\text { Meningkatkan kualitas SDM pengelola BMD dalam penyusunan laporan } \\
\text { BMD }\end{array}$ & 6.363 & 1 \\
\hline 4. & $\begin{array}{l}\text { Meningkatkan evaluasi rutin dan pengawasan internal yang efektif untuk } \\
\text { meningkatkan kepatuhan terhadap peraturan perundang-undangan } \\
\text { implementasi pengelolaan BMD }\end{array}$ & 6.023 & 3 \\
\hline 5. & 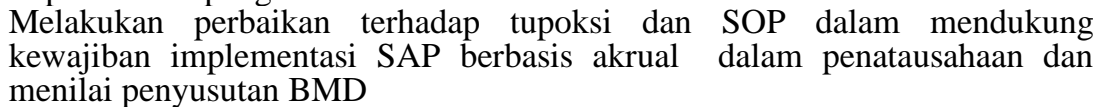 & 5.970 & 5 \\
\hline 6. & $\begin{array}{l}\text { Mengurangi perpindahan atau mutasi aparatur pengelola BMD dengan } \\
\text { mengalokasikan anggaran dalam peningkatan kinerja pengelola BMD }\end{array}$ & 5.957 & 6 \\
\hline
\end{tabular}
Sumber: Data diolah (2017)

\section{Perancangan program}

Berdasarkan strategi utama peningkatan kualitas laporan keuangan yang dipilih berdasarkan hasil analisis QSPM maka selanjutnya perlu dilakukan perancangan program dalam rangka pelaksanaan strategi prioritas tersebut. Dalam pelaksanaan strategi diperlukan acuan sehingga pelaksanaannya menjadi lebih mudah untuk dilakukan. Perlu disusun kebijakan operasional sehingga dapat menjadi arahan dalam melaksanakan program dan kegiatan dalam peningkatan pengelolaan BMD pada Pemerintah Kabupaten Kepulauan Anambas. perancangan program dan kegiatan disajikan dalam 6 Tabel

Tabel 6. Implementasi strategi peningkatan pengelolaan BMD Pemerintah Kabupaten Kepulauan Anambas

\begin{tabular}{|c|c|c|c|}
\hline Strategi & Kebijakan & Program & Kegiatan \\
\hline $\begin{array}{lcr}\text { Meningkatkan } & \text { kualitas } & \text { SDM } \\
\text { pengelola } & \text { BMD } & \text { dalam } \\
\text { penyusunan laporan BMD } & \end{array}$ & $\begin{array}{l}\text { Pengelolaan BMD } \\
\text { yang tertib } \\
\text { adminsitrasi dan } \\
\text { akuntabel dalam } \\
\text { mempertahankan } \\
\text { opini WTP }\end{array}$ & $\begin{array}{l}\text { Program } \\
\text { Pembinaan dan } \\
\text { Pengembangan } \\
\text { Aparatur }\end{array}$ & $\begin{array}{l}\text { 1. Penyelenggaraan diklat teknis } \\
\text { pengelolaan BMD. } \\
\text { 2. Bimbingan teknis Penyelenggaraan } \\
\text { Sistem Pengendalian Intern } \\
\text { 3. Tugas belajar. }\end{array}$ \\
\hline $\begin{array}{l}\text { Peningkatan kinerja pengelola } \\
\text { BMD }\end{array}$ & & $\begin{array}{l}\text { Pembinaan } \\
\text { pengawasan } \\
\text { pendampingan }\end{array}$ & $\begin{array}{l}\text { Sosialisasi pemberian reward and } \\
\text { punishmet tentang pengelolaan BMD. }\end{array}$ \\
\hline $\begin{array}{l}\text { Meningkatkan evaluasi rutin dan } \\
\text { pengawasan internal yang efektif } \\
\text { untuk meningkatkan kepatuhan } \\
\text { terhadap peraturan perundang- } \\
\text { undangan implementasi } \\
\text { pengelolaan BMD }\end{array}$ & & $\begin{array}{l}\text { Program } \\
\text { evaluasi dan } \\
\text { monitoring }\end{array}$ & $\begin{array}{l}\text { 1. Melakukan pengawasan pengelolaan } \\
\text { BMD secara rutin. } \\
\text { 2. Pembinaan dan pengendalian terhadap } \\
\text { ASN serta pendampingan regenerasi } \\
\text { penggurus BMD. } \\
\text { 3. peningkatan koordinasi antar SKPD } \\
\text { dan pihak eksternal dalam mitigasi } \\
\text { resiko BMD }\end{array}$ \\
\hline $\begin{array}{l}\text { Menerapkan sanksi yang tegas } \\
\text { dalam mendukung komitmen } \\
\text { pimpinan BKD dalam melakukan } \\
\text { rekonsiliasi data aset daerah dan } \\
\text { keuangannya }\end{array}$ & & $\begin{array}{l}\text { Implementasi } \\
\text { Komintmen } \\
\text { setiap pimpinan } \\
\text { SKPD atas } \\
\text { kebijakan }\end{array}$ & $\begin{array}{l}\text { Pemberian sangsi terhadap SKPD, yaitu } \\
\text { penundaan proses pengeluaran SP2D } \\
\text { kegiatan apapun terhadap SKPD yang } \\
\text { belum melakukan rekonsialiasi. }\end{array}$ \\
\hline $\begin{array}{l}\text { Melakukan perbaikan terhadap } \\
\text { tupoksi dan SOP dalam } \\
\text { mendukung } \quad \text { kewajiban } \\
\text { implementasi SAP berbasis akrual } \\
\text { dalam penatausahaan dan menilai } \\
\text { penyusutan BMD }\end{array}$ & & $\begin{array}{l}\text { Penyusunan } \\
\text { revisi perbaikan } \\
\text { SOP } \\
\text { Pengelolaan } \\
\text { BMD }\end{array}$ & $\begin{array}{l}\text { Penyusunan revisi } \\
\text { pengelolaan BMD }\end{array}$ \\
\hline $\begin{array}{l}\text { Mengurangi perpindahan atau } \\
\text { mutasi aparatur pengelola BMD }\end{array}$ & & $\begin{array}{l}\text { Implementasi } \\
\text { koordinasi antar } \\
\text { pimpinan SKPD }\end{array}$ & $\begin{array}{l}\text { Meningkatkan koordinasi antar pimpinan } \\
\text { SKPD, yaitu BKPSDM dengan BKD } \\
\text { dalam merotasi dan mutasi setiap aparatur } \\
\text { pengelola/pengurus BMD. }\end{array}$ \\
\hline
\end{tabular}

Sumber: Data diolah (2017) 


\begin{tabular}{|c|}
\hline $\begin{array}{l}\text { Peningkatan } \\
\text { engembangan } \\
\text { empercepat proses pemahaman kepac } \\
\text { engelola BMD tentang pentingny } \\
\text { poran BMD untuk laporan keuanga }\end{array}$ \\
\hline
\end{tabular}

Berdasarkan hasil penelitian, bimbingan teknis ataupun diklat yang menjadi prioritas utama yang berkenaan dengan pengelolaan BMD ( aset daerah ) yang meliputi :

a) Diklat Teknis pengelolaan BMD/aset

$$
\begin{array}{ll}
\text { - diklat penatausahaan dan } \\
\text { pengamanan aset daerah; } \\
\text { - diklat penilaian BMD } \\
\text { - diklat penyusunan laporan } \\
\text { barang/aset; }
\end{array}
$$

b) Bimtek pengawasan dan pengendalian Internal.

c) Tugas Belajar

a. Penyelenggaraan diklat teknis Pengelolaan BMD

Terbitnya Permendagri Nomor 64 Tahun 2013 tentang Penerapan Standar Akuntansi Pemerintah berbasis Akrual, dijelaskan bagaimanana pengelolaan BMD harus menyesuaikan mulai memperhitungkan adanya penyusutan nilai aset serta melakukan pengelolaan BMD juga harus mengikuti ketentuan ataupun petunjuk teknis dalam Permendagri Nomor 19 Tahun 2016 tentang teknis pengelolaan BMD. Berdasarkan hasil wawancara dengan Kepala Bidang Aset Badan Keuangan Daerah diperoleh informasi bahwa selama ini diklat mengenai pengelolaan BMD belum pernah dilakukan di Kabupaten Kepulauan Anambas. Melalui pelaksanaan diklat teknis ini diharapkan dapat meningkatkan pemahaman pengelola BMD mulai dari perencanaan sampai dengan penghapusan dan terciptanya tertib administrasi tata kelola BMD yang baik dan akuntabel.

b. Bimbingan Teknis Sistem Pengawasan dan Pengendalian Intern

Berdasarkan hasil penelitian pada analisis rating scale diperoleh hasil bahwa pembinaan, pengawasan dan pengendalian terhadap pengelola BMD kurang baik dan belum sepenuhnya dilakukan secara optimal pada Pemerintah Kabupaten Kepulauan Anambas. Efektivitas pengawasan dan pengendalian internal pada setiap satuan kerja perangkat daerah sangat dipengaruhi oleh kompetensi sumber daya manusia serta pemahaman pimpinan terhadap sistem pengawasan dan pengendalian itu sendiri. Perlu dibangun pemahaman yang baik bagi pimpinan SKPD melalui pelatihan sistem pengendalian intern sehingga seluruh unsur pengendalian dapat dilaksanakan secara baik.

c. Pengembangan kapasitas aparatur dengan pemberian beasiswa tugas belajar.

Memberikan kesempatan bagi para apartur daerah yang bertugas sebagai pengurus barang yang bekinerja baik melanjutkan kualifikasi pendidikan.

\section{SIMPULAN DAN SARAN}

\section{Simpulan}

1. Masih terdapat kelemahan dalam implementasi penerapan dari proses perencanaan yang tidak dilakukan oleh SKPD yaitu tidak melakukan analisa perencanaan kebutuhan barang maupun kebutuhan pemeliharaan barang.

2. Penatausahaan dan pengamanan pengelolaan BMD perlu dilakukan 
pengawasan dan kontrol atasan yang lebih intensif dan berkelanjutan sebagai motivasi kendali dari pembinaan terhadap aparatur pengelola BMD khususnya pada lingkungan kerja SKPD yang tidak berjalan sesuai dengan aturan. Efektivitas sistem pengawasan dan pengendalian atasan adalah bentuk dari pembinaan yang erat kaitannya dengan kompetensi sumber daya manusia khususnya pimpinan instansi pemerintah daerah.

3. Berdasarkan hasil analisis SWOT yang dilakukan menunjukkan bahwa Lemahnya kompetensi SDM pengelola BMD disebabkan masih kurangnya pelatihan maupun sosialisasi yang dilakukan terhadap pengurus BMD. Dalam kondisi saat ini berbagai aturan dan kebijakan pengelolaan keuangan dan BMD terus diperbaharui sehingga kurangnya pemahaman pengelola BMD akan berdampak pada laporan BMD dan kualitas laporan keuangan yang dihasilkan.

\section{Saran}

1. Melaksanakan seluruh strategi yang sudah dirancang dengan komitmen dan konsisten serta mengaplikasikan proses pengelolaan BMD sesuai prosedur aturan yang berkelanjutan.

2. Melakukan pembinaan maupun sosialisasi bagi pimpinan instansi SKPD mengenai pemahaman terhadap sistem pengendalian intern pengamanan BMD.

3. Meningkatkan koordinasi antar pimpinan SKPD, BKPSDM dengan BKD dalam merotasi dan mutasi setiap aparatur pengurus BMD.

4. Mengalokasikan anggaran honor untuk pengelola, pengurus dan pengurus pembatu BMD yang berkelanjutan.

\section{DAFTAR PUSTAKA}

[BPKRI] Badan Pemeriksa Keuangan RI Perwakilan Provinsi Kepri. 2015. Laporan Hasil Pemeriksaan Provinsi Kepulauan Riau. Batam (ID): BPK.
BPPK Kemenkeu Republik Indonesia. 2013. Pembinaan, Pengawasan, dan Pengendalian Barang Milik Negara. Jakarta.

2010. Penatausahaan Barang Milik Negara. Jakarta.

2010. Pengamanan dan

Pemeliharaan Barang Milik Negara. Jakarta.

2013. Penilaian Barang Milik Negara (non tanah dan angunan). Jakarta.

Halim, A. 2013. Faktor-faktor yang Mempengaruhi Pengelolaan Aset Pasca Pemekaran Wilayah dan Pengaruhnya Terhadap Kualitas Laporan Keuangan Pemerintah di Kabupaten Tapanuli Selatan. Jurnal Ekonomi dan Bisnis.

[KEMENDAGRI] Kementerian Dalam Negeri RI. 2013. Peraturan Menteri Dalam Negeri Nomor 64 tahun 2013 tentang Penerapan Standar Akuntansi Berbasis Akrual pada Pemerintah Daerah. Jakarta (ID) : Kemendagri.

[KEMENDAGRI] Kementerian Dalam Negeri RI. 2016. Peraturan Menteri Dalam Negeri Nomor 19 tahun 2016 tentang tentang Pedoman Pengelolaan Barang Milik Daerah. Jakarta (ID) : Kemendagri.

Kinnear, T. C. dan Taylor, J. R. 1991. Riset Pemasaran. Terjemahan. Jilid I. Erlangga, Jakarta.

Oktaviana. 2010. Pengelolaan Aset Daerah Berkaitan Opini Disclaimer BPK di Kabupaten Toja Una Una di Provinsi Sulawesi Tengah Tahun 2007. Jurnal Repository UGM. Diakses 16 Sepetember 2016.

Riduwan. 2010. Skala Pengukuran Variabel-variabel Penelitian. Bandung (ID): Alfabeta.

Sikki, M.1999. Pengaruh Pengawasan Terhadap Pelaksanaan Pengelolaan Barang pada Pemerintah Daerah 
Khusus Ibukota Jakarta. Tesis S2 Program Pasca Sarjana UI. Jakarta.

Siregar, D. 2004. Manajemen Aset. Jakarta. Satyatama Graha Tara.
Soleh, C. Rochmansjah H. 2010. Pengelola

Keuangan dan Aset Daerah, Jakarta (ID) Fokusmedia.

Suwanda, D. 2015. Optimalisasi Pengelolaan Aset Pemda. Cetakan III Jakarta. PPM. 


\section{Lampiran 1. Matriks SWOT dan Alternatif Strategi Peningkatan Pengelolaan BMD}

\begin{tabular}{|c|c|c|}
\hline \multirow[b]{2}{*}{ IFE } & S - KEKUATAN & W - KELEMAHAN \\
\hline & $\begin{array}{l}\text { 1. Kebijakan Pemerintah Daerah } \\
\text { dalam mendukung pengelolaan } \\
\text { BMD. } \\
\text { 2. Manajemen dan Struktur } \\
\text { Organisasi tupoksi yang jelas } \\
\text { bagi pengelola BMD } \\
\text { 3. Komitmen pimpinan BKD yang } \\
\text { kuat dalam pengelolaan BMD } \\
\text { tentang rekosiliasi data aset dan } \\
\text { keuangan. } \\
\text { 4. Adanya Standar Operasional } \\
\text { Prosedur (SOP) dalam } \\
\text { penyusunan laporan BMD } \\
\text { 5. Ketersediaan sarana pendukung } \\
\text { penyusunan laporan BMD yang } \\
\text { memadai } \\
\text { 6. Aparatur pengelola BMD secara } \\
\text { kuantitas cukup memadai }\end{array}$ & $\begin{array}{l}\text { 1. Lemahnya kompetensi SDM } \\
\text { pengelola BMD di SKPD } \\
\text { 2. Pemantauan dan pengawasan } \\
\text { BMD yang berkelanjutan belum } \\
\text { memadai. } \\
\text { 3. Keterbatasan pagu anggaran } \\
\text { dalam peningkatan kinerja } \\
\text { pengelola dan pengurus BMD } \\
\text { 4. Pelatihan dan sosialisasi } \\
\text { pengelolaan BMD kurang } \\
\text { memadai. } \\
\text { 5. Kompensasi dan penghargaan } \\
\text { atas prestasi pegawai pengelola, } \\
\text { pengurus BMD belum memadai } \\
\text { 6. Belum optimalnya sumberdaya } \\
\text { Aparatur pengelola BMD di } \\
\text { SKPD dalam menerapkan } \\
\text { Standar Operasional Prosedur } \\
\text { (SOP). }\end{array}$ \\
\hline \multicolumn{3}{|l|}{ O - PELUANG } \\
\hline $\begin{array}{l}\text { 1. Pemberian insentif/honorarium } \\
\text { bagi pengelola BMD dalam } \\
\text { meningkatkan kinerja } \\
\text { 2. Kebijakan implementasi } \\
\text { Permendagri Nomor } 64 \text { tahun } \\
2013 \text { tentang SAP berbasis } \\
\text { akrual dalam penyusunan } \\
\text { laporan aset dan keuangan } \\
\text { daerah. } \\
\text { 3. Peningkatan pelaksanaan } \\
\text { pengawasan melekat oleh } \\
\text { pimpinan SKPD. } \\
\text { 4. Pemberian sanksi kepada } \\
\text { SKPD yang belum melakukan } \\
\text { rekonsiliasi data belanja aset } \\
\text { dan keuangan } \\
\text { 5. Kerjasama dengan lembaga } \\
\text { BPKP dalam evaluasi } \\
\text { pengelolaan dan laporan BMD }\end{array}$ & \begin{tabular}{l}
\multicolumn{1}{c}{ STRATEGI S - O } \\
1. Meningkatkan kinerja pengelola \\
BMD $(\mathrm{O} 1, \mathrm{O} 2, \mathrm{O} 3, \mathrm{O} 4, \mathrm{~S} 1, \mathrm{~S} 2, \mathrm{~S} 3$, \\
S4, S5,S6) \\
2. Menerapkan sanksi yang tegas \\
dalam mendukung komitmen \\
pimpinan BKD dalam \\
melakukan rekonsiliasi data \\
keuangan dan aset daerah. (S3, \\
S5, O5,O6)
\end{tabular} & $\begin{array}{l}\text { STRATEGI W - O } \\
\text { 1. Meningkatkan kualitas SDM } \\
\text { pengelola BMD dalam } \\
\text { penyusunan laporan BMD. } \\
\text { (O1,O2, W1,W4,W6) } \\
\text { 2. Meningkatkan evaluasi rutin dan } \\
\text { pengawasan internal yang efektif } \\
\text { untuk meningkatkan kepatuhan } \\
\text { pada aturan dalam implementasi } \\
\text { pengelolaan BMD (O2, O3, O4, } \\
\text { W2,W6) }\end{array}$ \\
\hline \multicolumn{3}{|l|}{ T - ANCAMAN } \\
\hline $\begin{array}{l}\text { 1. Rendahnya kepatuhan terhadap } \\
\text { peraturan perundang-undangan } \\
\text { 2. Perubahan masa kepemimpinan } \\
\text { kepala daerah } \\
\text { 3. Mutasi dan promosi jabatan } \\
\text { terhadap aparatur pengelola } \\
\text { BMD } \\
\text { 4. Perubahan SOTK pemerintah } \\
\text { daerah dengan pemberlakuan } \\
\text { PP } 18 \text { Tahun } 2016 \text {. } \\
\text { 5. Pengakuan hak pribadi / } \\
\text { kelompok / perusahaan atas } \\
\text { BMD (tanah) }\end{array}$ & $\begin{array}{l}\quad \text { STRATEGI S - T } \\
\text { 1. Melakukan perbaikan terhadap } \\
\text { tupoksi dan SOP dalam } \\
\text { mendukung kewajiban } \\
\text { implementasi SAP berbasis } \\
\text { akrual dalam menilai penyusutan } \\
\text { BMD (S1, S2, S3, S4, T1, T4, } \\
\text { T6) }\end{array}$ & $\begin{array}{l}\text { STRATEGI W - T } \\
\text { 1. Mengurangi perpindahan atau } \\
\text { mutasi aparatur pengelola BMD. } \\
(\mathrm{W} 2, \mathrm{~T} 2, \mathrm{~T} 3, \mathrm{~T} 4)\end{array}$ \\
\hline
\end{tabular}

Sumber: Data diolah (2017) 